\title{
Studies on the Stability of Casein
}

\author{
Fractionated Casein of Alcohol-labile Milk on DEAE-cellulose Column
}

\author{
Shunrokuro Arima, Ryoya Nikı and Yoshio Hashimoto \\ (Faculty of Agriculture, Hokkaido University) \\ (Received for Publication on March 2, 1965)
}

Aa a part of a series of studies conducted since 1962 on extensional. fields related to alcohol-labile milk ${ }^{4}$, a comparative study was conducted by the authors on casein fractions using DEAE-cellulose column in an attemt to compare alcohol-labile milk against normal milk.

\section{Matelials and Methods}

Alcohol-labile milk with normal acidity is seen in fall in Southern Hokkaido. Samples were taken from individual cows and details concerning milk compositions were reported ${ }^{4}$.

The preparations of skim milk and acid casein were described in our former reports ${ }^{2}$. Casein micelles and centrifuged whey were obtained from skim milk with Sharples Ultracentrifuge at $30,500 \mathrm{G}$ for 20 min at $5^{\circ} \mathrm{C}$. Casein micelles were washed with distilled water twice and dispersed in distilled water ${ }^{13)}$. Supernatant solution of alcohol-labile milk on alcohol test was prepared by centrifugation at $1,000 \mathrm{G}$ for $10 \mathrm{~min}$ to remove sediment.

Skim milk, centrifuged whey, casein micelle suspension and supernatant solution were treated in the following manner prior to chromatography. One mol solution of $\mathrm{K}_{2} \mathrm{C}_{2} \mathrm{O}_{4}$ was added to those solutions at a rate of $10 \%$ volume. These mixtures were kept at $2^{\circ} \mathrm{C}$ for one hour and were centrifuged at $2,000 \mathrm{G}$ at $2^{\circ} \mathrm{C}$ in order to remove calcium-oxalate. These supernatant solutions were dialysed with $0.02 \mathrm{M}$ phosphate buffer ${ }^{8 /}$.

The method of chromatography on DEAE-cellutose column was described in our recent reports ${ }^{2,8)}$. Effluent diagrams of chromatography were obtained by measuring optical density at $280 \mathrm{~m} \mu$ using a Hitachi spectrophotometer. Area of individual peaks of effluent diagram was measured with a planimeter and were shown as relative amounts (\%) of total area of peaks eluted.

\section{Results}

Table 1 gives the compositions of eluting buffers used. Table 2 and 3 show the relative amounts (\%) of peaks fractionated from normal milk and alcohol-labile milk.

According to GoRDon et al. ${ }^{8)}, \alpha-, \beta-$ and $\gamma$-casein contain different amino acid composition and so fractionated caseins are assumed to exhibit different ultraviolet absorption at $280 \mathrm{~m} \mu$ under the same concentration of nitrogen. On the basis of these facts, it seems reasonable that though the ultraviolet absorption of each fractionated casein is not proportional to the content of the fraction, the relative amounts of each fraction can be possibly compared to recognize the differences among samples.

Jap. J. Zootech. Sci., 36, (8). 
Studies on the stability of casein

Table 1. Composition of eluting buffers

\begin{tabular}{|c|c|c|}
\hline Buffer, No. & $\begin{array}{l}\mathrm{NaCl} \text { or } \mathrm{NaOH} \\
\text { concentration* }\end{array}$ & $\mathrm{pH}$ \\
\hline 1 & $0.000 \mathrm{M} \mathrm{NaCl}$ & 7.00 \\
\hline 2 & 0.050 & 7.00 \\
\hline 3 & 0.075 & 7.00 \\
\hline 4 & 0.100 & 7.00 \\
\hline 5 & 0.125 & 7.00 \\
\hline 6 & 0.150 & 7.00 \\
\hline 7 & 0.175 & 7.00 \\
\hline 8 & 0.200 & 6.98 \\
\hline 9 & 0.225 & 6.98 \\
\hline 10 & 0.250 & 6.97 \\
\hline 11 & 0.275 & 6.97 \\
\hline 12 & 0.300 & 6.95 \\
\hline 13 & 0.325 & 6.95 \\
\hline 14 & 0.350 & 6.95 \\
\hline 15 & 0.500 & 6.93 \\
\hline 16 & 1.000 & 6.85 \\
\hline 17 & $0.1 \mathrm{~N} \mathrm{NaOH}$ & \\
\hline 18 & $0.2 \quad \prime \prime$ & \\
\hline
\end{tabular}

* In $0.02 \mathrm{M}$ phosphate buffer, $\mathrm{pH} 7,0$.

Table 2. Relative amounts (\%) of individual peaks eluted from normal milk

\begin{tabular}{l|rrrrrrrrrrrrr|r}
\hline \multicolumn{1}{c|}{ Eluting buffer, No. } & 7 & 8 & 9 & 10 & 11 & 12 & 13 & 14 & 15 & 16 & 17 & 18 & Total \\
\hline Acid casein solution & - & - & 1.8 & 3.6 & 6.6 & 9.1 & 19.5 & 21.8 & 15.8 & 4.3 & 2.2 & 15.3 & 100 \\
Skim milk & 4.2 & 4.2 & 3.4 & 4.2 & 8.7 & 11.6 & 25.4 & 15.8 & 7.6 & 2.7 & 3.1 & 9.1 & 100 \\
Casein-micelle solution & 0.8 & 1.4 & 3.1 & 5.2 & 15.1 & 16.4 & 26.9 & 13.1 & 5.1 & 1.4 & 1.0 & 10.5 & 100 \\
Centrifuged whey & 27.3 & 12.6 & 4.2 & 3.9 & 7.4 & 6.7 & 10.9 & 7.6 & 5.3 & 2.5 & 3.0 & 8.6 & 100 \\
\hline
\end{tabular}

Table 3. Relative amounts (\%) of individual peaks eluted from alcohol-labile milk

\begin{tabular}{l|rrrrrrrrrrrrrr|r}
\hline \multicolumn{1}{c|}{ Eluting buffer, No. } & 7 & 8 & 9 & 10 & 11 & 12 & 13 & 14 & 15 & 16 & 17 & 18 & Total \\
\hline Acid casein solution & - & - & 1.7 & 2.2 & 2.5 & 9.3 & 17.5 & 27.3 & 18.2 & 3.4 & 5.3 & 12.6 & 100 \\
Skim milk & 3.3 & 5.6 & 5.2 & 3.9 & 8.0 & 9.6 & 19.5 & 17.9 & 8.8 & 3.0 & 3.9 & 11.3 & 100 \\
Casein-micelle solution & 0.7 & 1.4 & 2.7 & 3.6 & 7.5 & 9.8 & 25.3 & 19.3 & 9.9 & 3.1 & 7.1 & 11.6 & 100 \\
$\begin{array}{l}\text { Centrifuged whey } \\
\begin{array}{l}\text { Supernatant on alcohol- } \\
\text { test }\end{array}\end{array}$ & 7.7 & 23.4 & 16.6 & 3.8 & 4.6 & 4.7 & 8.2 & 6.7 & 5.0 & 2.5 & 8.6 & 8.2 & 100 \\
\hline
\end{tabular}

In Table 2, casein micelle solution shows a decrease in amounts of peaks eluted by buffers, No. 7, 8, 14, 15 and 16 and an increase in amounts of peaks eluted by buffers, No. $11 ; 12$ and 13 in comparison with skim milk. In Table 3, supernatant solution shows lesser amounts of peaks eluted by buffers, No. 9, 14 and 15 than skim milk.

NAGASAWA et al. ${ }^{7}$ reported that an increasing in relative amount of $\gamma$-casein and a decreasing in $\beta$-casein were noticed in abnormal milk. There are few reports concerning the distribution 


\section{ARIMA - NIKI - HASHIMOTO}

of each casein in alcohol-labile milk. Therefore, area of peaks eluted by buffers, No. 7 to 18 were divided into four groups in order to recognize the difference of the distribution of caseins between alcohol-labile milk and normal milk. The first group are peaks eluted by buffers, No. 7 and 8 which were reported $\left.{ }^{8,11}\right)$ to contain $\beta$-lactoglobulin and $\gamma$-casein. The second group are peaks eluted by buffers, No, 9, 10 and 11 which contain $\beta$-casein rich $^{8,11)}$. The third group are peaks eluted by buffers, No, 12 to 16 which contain $\alpha$-casein rich ${ }^{8,11)}$. The fourth group are peaks eluted by buffers, No. 17 and 18 which contain $\kappa$-casein rich ${ }^{8,11)}$. The results of the distributions of four groups are shown in Table 4.

Table 4. Comparison of relative amounts of peaks divided into several groups between alcohol-labile milk and normal milk

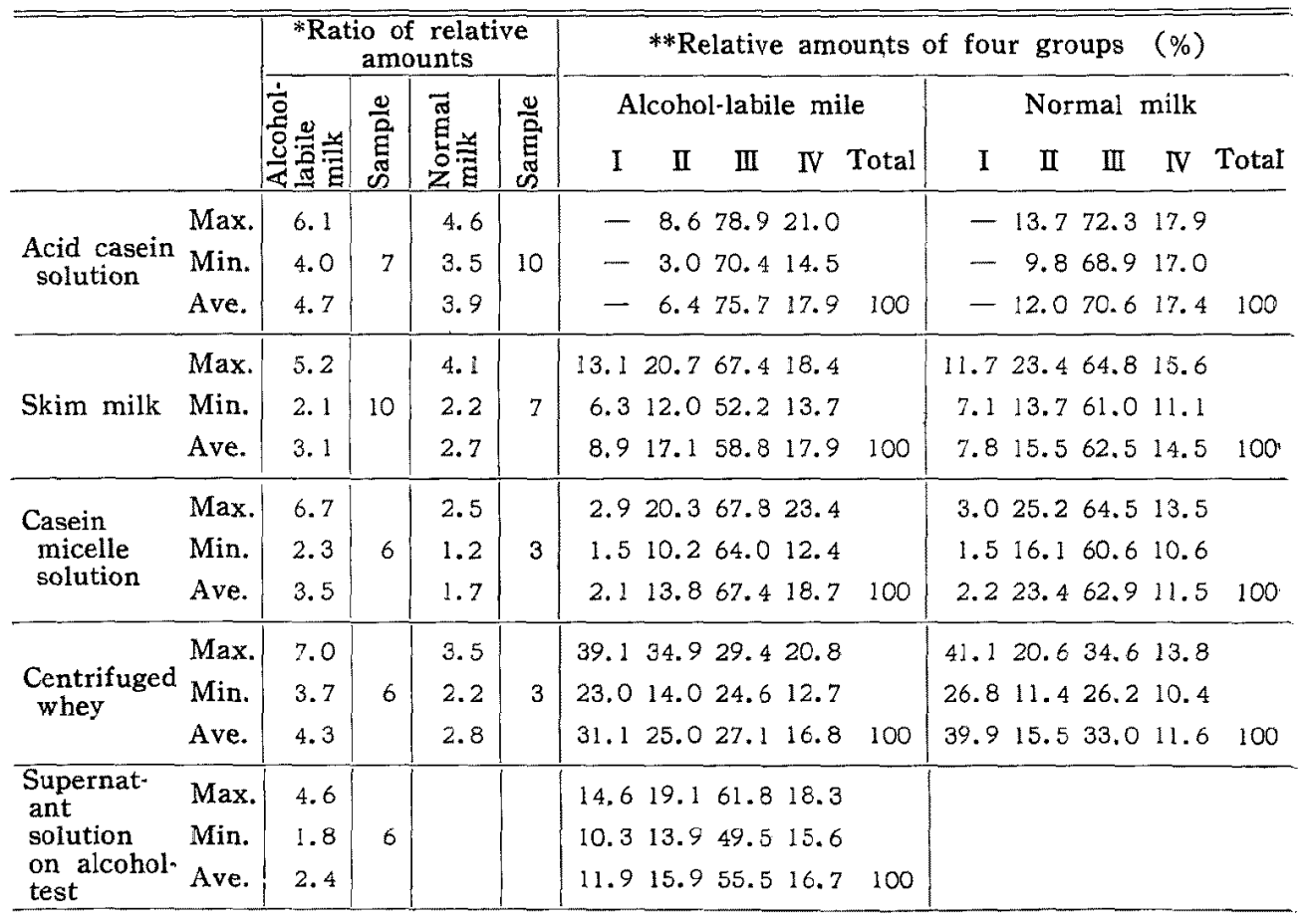

* Ratio of the sum-total of relative amounts of two peaks eluted by buffers, No. 11, 12 against total amounts of six peaks eluted by buffers; No. 9, 10, 13, 14, 15, 16.

** Relative amounts of four groups:

I : Sum-total of amounts of two peaks eluted by buffers, No. 7,8 .

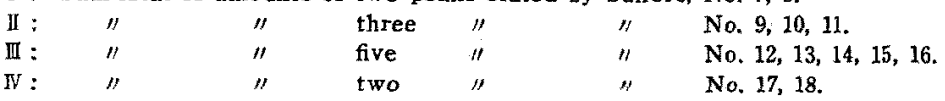

In our recent reports ${ }^{2,8}$, peaks eluted by buffers, No. 11 and 12 were more stable to. calcium ion, magnesium ion and alcohol solution than other peaks eluted by buffers, No. 9 to 16. The ratio of the total of amounts of two peaks eluted by buffers, No. 11 and 12 ; against total amounts of six peaks of No.9,10,13,14,15 and 16 is shown in Table 4 likewise, comparing alcohol-labile milk with normal milk. In Table 4, alcohol labile milk shows higher amount of the fourth group in average in all cases than normal milk. In Table 4 also, alcohol-labile milk shows higher average value of the ratio in all case than normal milk. This fact means that alcohol-labile milk has lesser amounts of peaks eluted by buffers, No. 11 and 12 than normal milk. But differences between maximum and minimum values in both 
Studies on the stability of casein

Table 5. Comparison of relative amounts of peaks from skim milk eluted between alcohol-test positive milk and negative milk obtained from the same cow after the feed was improved.

\begin{tabular}{|c|c|c|c|c|c|c|c|c|c|c|c|c|}
\hline Eluting buffer, No. & 7 & 8 & 9 & 10 & 11 & 12 & 13 & 14 & 15 & 16 & 17 & Total \\
\hline $\begin{array}{l}\text { Alcohol-test, } \\
\text { positive milk }\end{array}$ & 2.2 & 4.9 & 4.8 & 2.4 & 4.8 & 11.5 & 25.1 & 18.7 & 8.8 & 3.3 & 1.312 .2 & 100 \\
\hline \multirow[t]{2}{*}{$\begin{array}{l}\text { Alcohol-test, } \\
\text { negative milk }\end{array}$} & 0.8 & 1.5 & 3.0 & 6.3 & 12.5 & 15.3 & 24.2 & 15.1 & 7.5 & 2.7 & $2.9 \quad 8.2$ & 100 \\
\hline & \multicolumn{4}{|c|}{$\begin{array}{l}\text { Ratio of relative } \\
* \text { amounts of groups }\end{array}$} & \multicolumn{7}{|c|}{\begin{tabular}{|cccc}
$* *$ Relative amounts of four & groups $(\%)$ \\
I & II & III & IV
\end{tabular}} & Total \\
\hline $\begin{array}{l}\text { Alcohol-test, } \\
\text { positive milk }\end{array}$ & \multicolumn{4}{|c|}{$1: 3.6$} & \multicolumn{2}{|c|}{7.1} & \multicolumn{2}{|c|}{12.0} & \multicolumn{2}{|c|}{67.4} & 13.5 & 100 \\
\hline $\begin{array}{l}\text { Alcohol-test, } \\
\text { negative milk }\end{array}$ & \multicolumn{4}{|c|}{$1: 2.1$} & & 2.3 & \multicolumn{2}{|c|}{21.8} & \multicolumn{2}{|c|}{64.8} & 12.1 & 100 \\
\hline
\end{tabular}

*, ** The same as described in Table 4.

relative amounts of four groups and the ratio in alcohol-labile milk are too large to compare clearly amounts of peaks with normal milk.

Another experiment ${ }^{4}$ was performed to change alcohol-labile milk to normal milk by improving the feed quality given to cows. In Table 5, relative amounts of peaks eluted are compared between alcohol-labile milk obtained up to the time that the feed was improved and normal milk obtained from the same cow after the diet proved proper satisfactory ${ }^{4)}$. Alcohol test positive milk showed an increasing in value of the ratio and amounts of the third and fourth groups and a decreasing in amounts of the first and second groups compared with alcohol test negative milk obtained from the same cow.

\section{Discussion}

From the results in Table 2, casein micelles were assumed to consist of peaks eluted by buffers, No. 11, 12,13,14 and 18 mainly. From the results on supernatant solution and skim milk in Table 3, sediment in alcohol-labile milk on alcohol test is assumed to be observed at

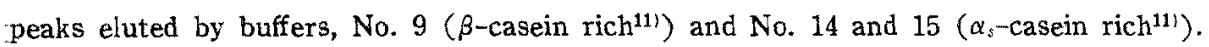

The following experiments were performed. Table 6 shows the contents of sialic acid ${ }^{51}$ found in individual peaks eluted by buffers, No. 7 to 18 . The peak eluted by buffer, No. 18 shows the highest amount of sialic acid because the peak contains $\kappa$-casein bound with sialic acid $^{(1)}$. Peaks eluted by buffers, No. 10,11 and 12 show also higher amounts of sialic acid than other peaks.

Table 6. Sialic acid content found in individual peak eluted (\%)

\begin{tabular}{l|cccccccccccc}
\hline Eluting buffer, No. & 7 & 8 & 9 & 10 & 11 & 12 & 13 & 14 & 15 & 16 & 17 & 18 \\
\hline $\begin{array}{l}\text { Skim milk } \\
\text { Acid casein }\end{array}$ & $0.01 *$ & 0.29 & 0.21 & 0.51 & 0.66 & 0.29 & 0.08 & 0.14 & 0.17 & - & -0.8 \\
\hline
\end{tabular}

* The sialic acid content calculated on the base of protein $\left(\frac{\text { sialic acid }}{\mathbf{N} \times 6.38} \times 100\right)$. 


\section{Arima - NikI - Hashlmoto}

According to Dumas et al. ${ }^{8}$ and $Y_{A G u c h i}$ et al. ${ }^{12)}$ a large portion of $\kappa$-casein is eluted between $\alpha$-casein and $\beta$-casein on DEAE-cellulose column. However, peaks eluted by buffers, No. 11 and 12 showed electrophoretically ${ }^{81} \alpha$-casein and $\beta$-casein components and a sensitivity to calcium ion which was lower than other peaks ${ }^{81}$. Kappa casein showed no sensitivity ${ }^{9 !}$. Therefore, these peaks are considered to consist of not only $\kappa$-casein but also $\alpha$-casein and $\beta$-casein.

In table 7 , the effect of an addition of $\mathrm{K}_{2} \mathrm{C}_{2} \mathrm{O}_{1}$ on relative amounts of individual peaks of effluent diagram in skim milk is shown, comparing the case as described in the method with the case without adding $\mathrm{K}_{2} \mathrm{C}_{2} \mathrm{O}_{4}$ prior to chromatography. An addition of $\mathrm{K}_{2} \mathrm{C}_{2} \mathrm{O}_{4}$ resulted in a decrease in amounts of peaks eluted by buffers, No. 11 and 12 and results in an increase in amounts of peaks eluted by buffers, No. $14,15,16,17$ and 18 . WAUGH et al. ${ }^{9}$ reported that $\alpha$-casein, $\beta$-casein, $k$-casein and other minor casein formed particles and calcium ion could form links between these caseins.

Table 7. Effect of an addition of $\mathrm{K}_{2} \mathrm{C}_{2} \mathrm{O}_{4}$ on relative amounts of individual peaks eluted

\begin{tabular}{|c|c|c|c|c|}
\hline \multirow{2}{*}{$\begin{array}{c}\text { Eluting } \\
\text { buffer, No. }\end{array}$} & \multicolumn{2}{|c|}{ Sample 1} & \multicolumn{2}{|c|}{ Sample 2} \\
\hline & Non addition & $\begin{array}{c}\text { Addition of } \mathrm{K}_{2} \mathrm{C}_{2} \mathrm{O}_{4} \\
(1 \mathrm{M} .10 \%)\end{array}$ & Non addition & $\begin{array}{l}\text { Addition of } \mathrm{K}_{3} \mathrm{C}_{2} \mathrm{O}_{4} \\
(1 \mathrm{M} .10 \%)\end{array}$ \\
\hline 1 & - & - & 1.1 & 1.6 \\
\hline 2 & 1.6 & 1.4 & 1.7 & 1.9 \\
\hline 3 & 1.4 & 1.1 & 1.3 & 1.4 \\
\hline 4 & 2.2 & 1.2 & 1.6 & 1.5 \\
\hline 5 & 4.4 & 3.4 & 5.0 & 4.2 \\
\hline 6 & 3.0 & 2.4 & 1.9 & 2.7 \\
\hline 7 & 4.7 & 1.4 & 1.6 & 4.1 \\
\hline 8 & 5.4 & 4.7 & 5.6 & 5.6 \\
\hline 9 & 2.8 & 5.3 & 5.2 & 4.1 \\
\hline 10 & 2.2 & 2.6 & 3.2 & 3.4 \\
\hline 11 & 7.2 & 4.1 & 6.6 & 4.2 \\
\hline 12 & 12.2 & 7.9 & 9.8 & 7.5 \\
\hline 13 & 14.3 & 10.7 & 14.1 & 9.6 \\
\hline 14 & 15.3 & 21.2 & 17.7 & 19.5 \\
\hline 15 & 10.0 & 13.1 & 10.4 & 12.6 \\
\hline 16 & 2.6 & 3.2 & 2.1 & 2.6 \\
\hline 17 & 3.3 & 7.9 & 3.6 & 8.7 \\
\hline 18 & 7.4 & 8.4 & 7.1 & 4.8 \\
\hline Total & 100 & 100 & 100 & 100 \\
\hline
\end{tabular}

In Table 5, sialic acid contents in peaks of No. 10,11 and 12 eluted from skim milk are higher than acid casein. In Table 2, 3 and 4, skim milk shows higher amounts of peaks of No. 11 and 12 but lesser amounts of peaks of No. 14, 15 and 18 than acid casein solution. From these results, it seems that $\alpha$-casein and $\alpha$-casein with $\beta$-casein form complex by the links of calcium partly, though the form of binding of the three types of casein are not clear yet, and these complex in skim milk are dissociated into free casein species on DEAE. cellulose column relatively less than in acid casein solution and skin milk added with $\mathrm{K}_{2} \mathrm{C}_{2} \mathrm{O}_{4}$ because calcium bound to casein is removed by acidifying and addition of $\mathrm{K}_{2} \mathrm{C}_{2} \mathrm{O}_{4}$ respectably. 
In Table 4, it might be that, because casein complex in alcohol-labile milk dissociate into each casein on DEAE-cellulose column under the same process of acidifying and addition of $10 \%$ volume of $\mathrm{K}_{2} \mathrm{C}_{2} \mathrm{O}_{4}$ more easily than in normal milk, alcohol-labile milk shows lesser amounts. of peaks of No. 11 and 12 and higher amounts of other peaks than normal milk in average value. But variations between maximum and minimum values in relative amounts of peaks. eluted were too large to discuss in details about the properties of casein complex in alcohollabile milk.

Wavgr et al. ${ }^{10}$ found that the association between free casein species and micelles was. affected by the concentration of calcium, phosphate etc. MAENO reported ${ }^{(6)}$ that alcohol-labile. milk was very variable in contents of soluble calcium and phosphorus.

It is interesting that alcohol test positive milk shows lesser amounts of peaks of No. 10 , 11 and 12 and higher amounts of peaks of No. 14, 15 and 18 than alcohol test negative milk obtained from the same cow after the feed was improved. But more samples should be tested.

\section{Summary}

Dialysed skim milk and casein solutions were fractionated by DEAE-cellulose column chromatography to compare alcohol-labile milk with normal milk.

1) Sediments in alcohol-labile milk on alcohol test consisted mostly of peaks eluted by 0.225 ( $\beta$-casein rich), 0.350 and $0.500 \mathrm{M} \mathrm{NaCl}$ ( $\alpha_{s}$-casein rich).

2) The peaks eluted by $0.250,0.275$ and $0.300 \mathrm{M} \mathrm{NaCl}$ showed relatively high sialic acid contents and were considered to consist of $\kappa$-casein, $\alpha$-casein and $\beta$-casein.

3) The variation of value in relative amounts of peaks eluted in alcohol-labile milk was. very large, so the difference in amounts of fractionated casein by DEAE-cellulose chromatography between alcohol-labile milk and normal milk was not clear.

\section{References}

1) Artma, S. (1964) Jap. J. Zootech. Sci., 35 (Suppl.) : 48.

2) Arima, S., S. Hori and Y. Hashimoto (1964) Jap. J. Zootech. Sci., $35: 130$.

3) Gordon, W.G., W.F. Semmett and M. Bender (1953) J. Amer. Chem. Soc., $75: 1678$.

4) Hashimoto, Y. and S. ARima (1964) Jap. J. Zootech. Sci., $35: 179$.

5) Kim., Y.K., S. ARIma and Y. Hashimoto (1965) Jap. J. Zootech. Sci., $36: 17$.

6) MAENo, M. (1952) Animal Husbandry, 6: 675.

7) Nagasawa, T. and T. Tanafashi (1963) Jap. J. Zootech. Sci., $33: 461$.

8) Ribadeau-Dumas, B. and B. Maubois (1964) Biochem. Biophys. Acta, $82: 494$.

9) WAUGH, D.F. (1961) J. Phys. Chem., $65: 1793$.

10) Waugh, D.F. and P.H. Hippel (1956) J. Amer. Chem. Soc., $78: 4576$.

11) Yaguchi, M. and N.P. TARAssuk (1961) J. Dairy Sci., $44: 589$.

12) Yaguchi, M. and N.P. TARASSUK (1964) J. Dairy Sci., $47: 1167$.

13) Yoshida, S., S. ARrma and Y. Hashimoto (1963) Jap. J. Zootech. Sci., $34: 375$. 


\section{ARIMA - NIKI - HASHMOTO}

\section{力ゼインの安定性に関する研究 \\ フルコール不安定乳カゼインの DEAE セルローズ分割について}

有馬俊六郎・仁木良哉・橋本吉雄

(北大䟴)

アルニール不安定乳カゼインを正常乳カゼインと比較 しながら DEAEーセルローズ分割試み次の結果学得 た.

1）フルコールテストの際，凝固沈激する蛋白柱さし $\tau 0.225,(\beta$-カ九゙イン) 乙 $0.350,0.500 \mathrm{M} \mathrm{NaCl}$ ( $\alpha \mathrm{S}$-カゼイン) で溶出されるカゼインである.

2) $0.250,0.275,0.300 \mathrm{M} \mathrm{NaCl}$ で溶出される区分
は，比較的シアル酸含量が多く，この区分は $\alpha$-カゼ

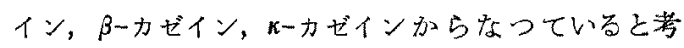
えられた。

3)一般にフルコール不安定乳の, 溶出される各䇣の面 積注，陚料間の変異が大きく，DEAE一セルローズに 上って各察の含量の差異を正常乳々正確に比䡛するこ とはできなかつた。 